\title{
Gagging the Past
}

This piece is concerned with the many ways in which the idea of gagging has been and could be connected to the idea of the past. There have been specific claims from Windschuttle and others that there has been a gagging of 'real' history founded in fact. But we might also see that reducing the past to 'proven' facts is to make a 'gag', a predigested narrative caricature that denies the past is something we must constantly make in the present. But could a 'gagging' of the past make us think about how writing the past is to engage with the possibility of a physical gagging that connects the past to a choking, a reflex connected to disgust and shame? This reflex via Darwin is connected to ideas of distance where we keep ourselves safe from the touch of the other, from the threat of the poison and perhaps the perpetuity of the past. If the past is embodied than how do we negotiate our relationship with it? And how should we write it? Can we eat it? This writing engages with the ambivalent affectivity of historical fact, narratives of the past and our relationship with a performed present that claims to be past. It is in short an intervention into the 'factual turn' that haunts a 'knowing' of the past.

\section{To Lecture Theatre}

(Lehmann, Reynolds and Windschuttle at the Wallace Theatre, Sydney University 2003)

It began by walking into the room, the lecture theatre. The lecture theatre opened her doors and let us in. Being soft food we moved easily through the dental formation of chairs — sitting quietly at first, within. But as more of us came this engorged gob forced us into cavities and small spaces in-between. Eventually we were organised into a thin spread over both sides of the stage area and at its front. Only the final table of 'debaters' prevented us disappearing down her throat. She was mostly accommodating. She let us rest easily in this rough mouth, bore our occasional rising and rubbing of her sides and since she was used to such filling food, her cheeks expanded to give us room to move. Because she loved us she didn’t chew or swallow. There was an energised calm. Even with this mouthful of folk there was an order as small bits of words rose and fell. But at some point there was an irritation, a connection set off between those at the sides and one prancing uvula like on the stage. It went on and she, the theatre, contracted in a direct response to this irritaion. We felt ourselves inside being forced against one and other, 
making the rubbing against the central stage figure more and more unbearable. She gagged and we were shot apart from each other. And then forced together again and shot apart. The past was too close.

In the uniland scape of Sydney University a re-enactment is taking place. Three men will speak for fifteen minutes each with five minutes rebuttal. There is a no nonsense legal professional as adjudicator. He suggests toughmindedness, the trust of law, the idea that this is where things are done fairly. This is the shape of mens; white men's, business. But on the edge is the feminine eye of academic dignity. She sits apart with grey hair and professional restraint. The building is brick (red brick actually) and the stage is simple. It is set only with chairs and tables and a Gleebooks sponsorship banner. Outside there are striped roofed wagons that sell ice cream and lollies that remind us of the ways in which candy connects the no-car streets of uniland to the no-car streets of Disneyland. A 'real' debate here is a try hard re-enactment with poor costumes.

Inside we have History displaying, managing, inventing and recalling itself for us. We have Windschuttle, Reynolds and Lehmann. Rightwing, leftwing and something. White, white and black. Historian, historian and contemporary context. Facts, facts and pain. Windschuttle will tell us again that there have been errors, serious errors in facts, historical method and that the transgressions of other historians can still be recovered through truth. Reynolds wants to tell us that these errors are unimportant and that historians must reaffirm history’s moral authority and political potency. Lehmann wonders what we do after the errors have been corrected-how do we, all of us, 'move on'.

In his opening speech Lehmann also says that this will be his last gig. That Windschuttle has created enormous pain for the communities of Tasmania. He is sick of the circus and thinks Reynolds and Windschuttle are staging a cockfight. The word cockfight resonates back from the description of them to us. We are set in rows that spread horizontally and our eyes look more across than the pitched microscopy of the cock ring but some of us would like blood, a trickle from a fast spur to the throat. How else will we know this sort 
of history: scientific, method driven —is dead unless we see its corpse? We carry the idea of these possible pleasures in how we have come. We have come with friends, lovers and partners and we meet more unexpectedly here. There is a lot of catching up and placement before the stage talking begins. We are almost a mob.

It is overcrowded and people begin to offer suggestions on how to seat everyone. Local Sydney identity (that is shorthand for Bob Gould; a left wing self styled anti-theory, antiwanker whose presence is as necessary at these things as a sausage at a barbie), makes many suggestions. Less well known but noticed are people from the scattered Sydney communities. There a face from Black and Pink, there an elder from La Perouse. If this communicates something of a flavour of knowns and unknowns or a ribald town meeting you have something of the local flavour of this event.

We listen to the others but we are waiting for Windschuttle. Perhaps we lean slightly closer to the stage, closer to him. He begins by thanking some people. There is a cry “What about thanking the Cadigal and Eora peoples, we are on their land?” He replies. Simple bile. "I have thanked the organisers and that is enough". Meaning, that's far enough. Meaning, I am already too close. And then when he is chewing air, flying away on an impressive, powerful list of why there was really no Indigenous resistance in Tasmania an woman stands and calls: "When are you going to sit down with some blackfellas, why are you too scared to just sit down and have a talk?” and for a second he is quiet before resuming his list, staring unseeingly ahead as he words his way to closure. Later in his five minute rebuttal, a thirty something man, shirtless but with white body paint rises and says: "You are hurting my black body, you are hurting us" and he has more to say but there are murmurs from the audience, from you, from we cock watchers and an educated, white, female voice says comparatively quietly from across the aisle 'Sit down, be quiet, lets have a rational debate". I am too slow to hiss but one of my friends turns and shsses and rolls her eyes. We are trying to shame this woman, this sister but of course this is not really a small town meeting, there is no shared community morality about good and bad things to say and the shaming fails. The man responds instantly to her. "Don’t you tell me to be quiet. Bodies are hurting. My Uncle died. I was taken away 
from my parents. I never knew I had any and that was in 1968- just over there in Camperdown. Don't you tell me to be quiet”. And later, finally, Windschuttle ends, innocent, sincere. 'I just want the facts, is that too much to ask?'

This event is symptomatic of our gagging relationship with the past. Is it too close? Is it touching us? Can we bear its touch? What stories keep it away from us? Will a factual narrative with its own quiet affective elements, where we breathe more shallowly, where our hearts increase their beating - is that touch just enough for us to believe in an end? A promised finale where you can breathe naturally again. And forget.

Are we being gagged? Perhaps this sandstone theatre is health, is diet. It may be preevolutionary like Darwin's healthy caged monkeys who simply vomit up what doesn't suit and go on. To vomit is to be healthy. We sit in this theatre and irritate its fabric uvula and its sandstone glossopalatine muscles and so we are crashed together and pulled apart as the soft palate of public debate rises to eject us. This is to lecture theatre, to be tossed out. Gagged.

But this gagging may also point to nothing more than the old fashioned, modern, indigestible form of facts and history as a science. The historical malady as bad food that leaves us incapable of making our own histories. You will fail to thrive on this indigestible stuff. We could see in this lecture theatre that to be gagged out plays a part in that. Windschuttle wants to be swallowed. He is certain his facts can sustain us but Reynolds has made even bolder claims to potency and a coming super nation made strong again by good factual history keeping at bay 'the circling theoreticians ${ }^{\text {'i }}$. That's me, that's Cultural Studies in the historical imagination - waiting for disciplinary History to weaken, to become carrion to our vulture ways.

These ideas of diet and digestion produce strange creatures. Looking at bodies on stage does not offer a transport. There is no phase of empowerment here but the enactment of certitude. I am facts; hear my voice, see my body. We sit so close we can see the debaters adams apples bob and in a moment of conflagration we touch. Without the screen to offer 
us other connections, other places, other times, we find ourselves marked as real and real again. And if only they were celebrities where we might care about their hair transplants and their most recent bodial regime as we watch and do not believe. But they are too certain and so are we. Grounded fact. Kantian dust.

\section{The Fragile Body}

In 1844 in northern NSW Edward Irby and three other men hunted a group of Aboriginal people, possibly members of the Bundgalung peoples into a gully. They lost them and then came upon them by chance, trapped beneath the hunters and so Irby and his fellow squatter Windeyer and two servants; Weaver and O’Connor killed the Aboriginal group. This was one part of an ongoing period of 'settlement' in the area.

Five days after the killing of the Aboriginal group, Irby writes, he 'Was seized with violent spasms, took a dose of Rhubarb and Magnesia but found no relief from it so took an emetic which gave me some ease, at night took some catechu and laudanum' (Wed 23, OM). This is not the first or the last time Irby reports being ill. Twice before he records bad headaches and being taken badly by dysentery which keeps him unwell for two days. And many months later, intermittently, he has several days in which he is 'unwell' but nothing again as dramatic as 'violent spasms'. And this is not the first 'expedition' against Aboriginal people that Irby has participated in although this is the first on 'his' land which has resulted in the deaths of Aboriginal people. Irby is not an innocent. This is not a simple tale of a sensitive soul.

'His' land lay between the furthest hills and the nearest river. His place was perhaps more than he could have previously imagined. What did it mean to become squatter? colonial? murderer? Beyond the 'limits of location', within the possibilities of transportative desires - what becomes of the so called 'human', now always historical, body in this colonial space? And what of the counter moves by peoples-the forces they bought to bear so often unrecorded so often seemingly unseen? Brady quotes Coetzee's description of space stretching out in front of the white man in a hot colony: 
The operation of space is thus: the five senses stretch out from the body they inhabit, but four stretch into a vacuum. The ear cannot hear, the nose cannot smell, the tongue cannot taste, the skin cannot feel: the sun bears down on the body, flesh and skin move in a pocket of heat, the skin stretches vainly around, everything is sun. Only the eyes have power. The eyes are free, they reach out to the horizon all around (Brady, 1996:66).

Brady is suggesting that the non-, within the vast spaces of Australia, 'loses any sense of limit' and that the experience of infinite space in turn provokes 'a kind of nihilistic violence' (Brady, 1996:67). The emotional and to some extent physical experience of being beyond the limits of one's cultural location and beyond ones spatial sensibility is nicely sketched here but perhaps it suggests too much. Coetzee's description is of senses overwhelmed by landscape and yet Brady's evocation of a nihilistic voyager assumes the omnipotence of these 'settler' experiences. It is an easy step to see these white men as nearly Gods; yet their bodies hurt. Individually, corporeally they had to struggle to maintain its new order. And always they were walking in land shaped and known by Indigenous peoples. After shooting the trapped group, Irby contains the meaning of his actions through the writing to the Lands Commissioner and through the reassurances of Windeyer, his fellow squatter, who reminds him he had had no choice but later his body is in 'violent spasms'. This reminds us that although he is God-like in his capacity to institute official silences, (his killings will never be officially recorded, will never become a Windschuttle fact) and although he can institute a very limited history he is also never entirely in control, never able to expunge the effects of being embodied. He is never without the possibility of being acted upon.

His methods of controlling his violent spasms is first to take rhubarb and magnesium. The rhubarb is to make him purge his bowels and the magnesium to then settle his stomach. But the spasms continue and so he takes something to make himself vomit which helps a little. At night he takes catechu, which settles the stomach and contracts the tissues and canals of the body. He combines this with laudanum or opium which would have relaxed all muscles and probably put him to sleep. He is still 'very bad' the next day, but is 'rather better' the day after that. He sticks to the catechu and laudanum. 
Thereafter he is back cutting the lambs (removing their tails and testes) and visits 'poor Robinson's grave' (a white shepherd killed by people) to check that the native dogs had not disturbed it. Have the fragile, semi-permeable, limits of this colonial body been reestablished?

The murdered, the unspoken of corpses, the efforts to make himself shit and vomit and the re-ordering through opium are powerful markers of this stranger body and rich in abjective possibilities. To paraphrase Kristeva; He expels himself, he spits himself out, he abjects himself within the same motion he establishes himself as a coherent colonial body (Kristeva, 1982:3). The corpses he has created have instituted a space beyond the locatable limits of location for himself but also for a simple past. His relationship with his ambiguously colonised space (squatting!) and with Indigenous people who constantly exceed any effort of containment through an imagining that they are discrete subjects means both bodies and time are rearranged. He is without borders. Intercorporeality and intertemporality.

He has the borders of his corpses oozing and writhing, sucking him out of himself but then he vomits and shits himself back into existence-or does he? For three days he is in an opium hollow where the body moves only haltingly at your command and where your world shrinks to small actions that you can minutely observe. Your own limits shrink back to the lifting of cups and the slow drift between sleep proper and daytime fug. The bowels and stomach retire and there is stillness. Little by little he moves out again. But it is not all OK.

There is no simple location for Irby for there is no simple location for the past. The narrative of Irby's reaction following the murders seems to assume a time of pure succession. Before there was Irby's conflicted body there must have been a body without conflict but this is not the case. Irby's body is an instance of emergence, an opportunity to see (fleetingly) the unpredictable properties of that which always needs the past, future and present to be. Irby's conflicted body may be able to temporarily establish some beachheads, ambiguously fortify self and Other yet he simultaneously remains a knowable horror. His murders destroy the idea of linear, progressive time; of growing up. They last, they haunt. They are embodied, sensual fact. They force place into being and are something more than memory. 


\section{Trained Narrative}

I am on a train from the Blue Mountains to Sydney when there is an announcement: 'This is the anniversary of the crash between this service and the Indian Pacific which occurred at 8:22 at this site four years ago. As a mark of respect for those killed and effected by that event I ask you to maintain a moments silence’.

I look at my watch. It is exactly 8:22. I am sitting in silence on exactly the same service that crashed. In that crash the first two carriages produced the greatest numbers of deaths. I am sitting in the first carriage. Perhaps they have changed the timetable for no Indian Pacific passes on cue. I remember in my silence that I used to occasionally share car lifts with a University of Western Sydney colleague who died in that crash. I realise I still don't believe she is dead. All that moment we are in silence the train keeps moving. This isn't quite an historical re-enactment and it isn’t quite a memorial. It feels very modern in its mechanical gait - we have no way of stopping. That is to monumentalise perhaps.

I wonder about the voice of the announcer. The drivers who I assume are also the announcers on this service are usually a proper reflection of multi-accented Sydney. They have been known to make the occasional small joke. 'Arriving Central 9:33 and twelve seconds' and once on a very wet day 'And a lovely day to be on the train'. But today we have a voice devoid of any noticeable accent or personality. Perhaps it is pure disappeared anglodom, ABC style with an added pedestrian inflection. It is sombre even funereal with no noticeable shift in tone between his call for silence and his announcements of next stops and times of arrival.

Is there an informal acceptance that 'Bob’ always does the memorial runs or might his oral control suggest a man on a work related recovery program- was he in that crash? now getting back in the saddle through a kind of speaking therapy?

He begins to give us more detail than we usually get. He is overservicing us. 'Seven minutes to Parramatta. This has become the limited stop service'. He tells us why we are slowing down even if it is only for a matter of seconds. He reminds us of other services and connections. 
But I am thinking of facts. It is a fact people died on this service. It has a useable past. It seems obvious what we should learn — don't travel on the 8:22. But every fact comes in a complex called an event and we calm bunnies know not to know that it has been proven we can die of this train.

And the announcer is going on. 'Seven minutes to Strathfield. There will be only two more stops, Strathfield and Central. Six minutes to Strathfield'. Suddenly I love this man. I realise he is talking us in. Smoothing any anxiety. Promising through this timed list, this service narrative, this eulogy of facts that we will arrive-safely. This is not the past. We are almost there. We know there is only five minutes to go.

\section{References}

Brady, Veronica (1996) Can these bones live? Sydney: Federation Press

Browne, Janet (1998) 'I could have retched all night': Charles Darwin and his body‘ in C.Lawrence and S.Shapin (eds) Science Incarnated:Historical Embodiments o Natural Knowledge, Chicago: University of Chicago Press

Darwin, Charles (1969) The Life and Letters of Charles Darwin, New York: Johnson Reprint Company Ltd

Davies, A. E. \& Kidd, D (1995) 'Pharyngeal sensation and gag reflex in healthy subjects' Lancet, Vol 345, Issue 8948, p.487

Irby, E. \& L. (1908) Memoirs of Edward and Leonard Irby, Sydney: William Brooks and Co.

Irby, Edward (1842-) Transcription of original diary. Available upon request.

Kristeva, Julie (1982) Powers of Horror: An Essay in Abjection, New York: Columbia University Press

Massumi, Brian (2002) Parables for the Virtual; Movement, Affect, Sensation, Durham: Duke University Press

Miller, W (1997) The Anatomy of Disgust, Cambridge, Massachusetts: Harvard University Press 
Nietzsche, Frederich, (1997) Untimely Meditations, Cambridge, New York: Cambridge University Press, pp. 1-39

Probyn, Elspeath (2000) Carnal appetites: Food Sex identities, Routledge, London pp. 137-39

Royzman, E \&Sabini, J (2001) 'Something it takes to be an emotion:The interesting case of disgust', Journal for the Theory of Social Behaviour, 31 (1):29, Mar 2001

Vattimo, Gianni (1993) The Adventure of Difference: Philosophy After Nietzsche and Heidegger, Baltimore: John Hopkins Press pp. 9-23

\footnotetext{
${ }^{\mathrm{i}}$ As quoted in the advertising leaflets for the debate. 'Contesting The Frontier:Truth and Method in Australian History’, Personal collection.
} 